\title{
Securities accounting control procedures as a tool for preventing economic crimes
}

\author{
Olga V. Burlakova*, and Victoria V. Saushkina \\ ${ }^{1}$ Orenburg state university, Prospekt Pobedy, 13, Orenburg, Orenburg Oblast, 460018, Russian \\ Federation
}

\begin{abstract}
This article offers a methodology of control procedures for checking the accounting of securities as a tool for preventing economic crimes. This methodology is proposed based on the analysis of investments in fixed assets and the dynamics of economic crimes in 2010-2018, the study of typical errors and violations. The methodology combines two sets of procedures: determining the effectiveness of purchased and available securities, as well as determining the completeness, reliability and information content of securities. The methodology of control procedures proposed by authors is aimed at timely detection and prevention of violations and fraudulent actions with securities.
\end{abstract}

\section{Introduction}

Economic entities in the process of carrying out their activities invest free cash in securities. It helps get money for those who need it from those who are willing to invest it in order to gain control over the activities of another business entity, additional income in the form of interest or dividends. At the same time, such investment of funds in securities is characterized by a high degree of risk of loss. Various violations and errors that occur in the accounting of securities have a negative impact on both the financial position of the business entity and the economy of our country. The relevance of the chosen research topic made it necessary to monitor accounting operations with securities, disclose reliable information, and prevent errors and violations in financial statements.

Many papers were devoted to the study of errors and violations in the accounting of securities [1-18]. Despite the considerable attention paid to these issues in this area, there are still accounting errors and misstatements in the financial statements of an economic entity. The purpose of this work is to develop a methodology for monitoring the availability and evaluation of securities in accounting and disclosure of information about them in accounting financial statements for the detection and prevention of economic crimes in the business activities of Russian business entities.

In accordance with this goal, the following tasks were solved:

- $\quad$ economic crimes in the Russian Federation are analyzed;

- typical errors and fraudulent actions in securities accounting have been identified;

\footnotetext{
* Corresponding author: burlak4@ rambler.ru
} 
- developed a methodology of control procedures for the availability and evaluation of securities of an economic entity to identify and prevent violations and fraud in the accounting of securities and disclosure of information about them in accounting financial statements.

In the process of scientific research, the authors used such methods and techniques as analysis, grouping, comparison, and a systematic approach.

The scientific novelty of the study is to develop a methodology for conducting control procedures for the presence and evaluation of securities in accounting and disclosure of information about them in accounting financial statements, aimed at timely detection and prevention of violations and fraudulent actions with securities.

The practical significance of the study consists in the wide use of control procedures for timely detection of errors, violations and prevention of fraudulent actions and economic crimes in the system of internal control of an economic entity, audit and economic examination of securities accounting.

Analysis of fixed capital investments in Russia shows that over the period from 2010 to 2018 , the number of investments increased from 6625 billion rubles to 13618 billion rubles, or 2.1 times (table.1). There is also a steady growth of investment in own funds by 2.7 times and investment in borrowed funds by 1.6 times. Foreign investment in 2018 decreased by 9.2 billion rubles compared to 2017, although it increased by 1.1 times compared to 2013 . Statistics show that every year the growth of investments from the issue of corporate bonds and the issue of shares increases by 8.1 and 2 times, respectively. This trend indicates that an increasing number of business entities in the course of their activities often use these assets to attract additional income.

Table 1. Investments in fixed assets of economic entities of the Russian Federation by sources of financing for 2010-2018 [16].

\begin{tabular}{|c|c|c|c|c|c|c|c|c|c|c|}
\hline \multirow{2}{*}{$\begin{array}{c}\text { Indicator's } \\
\text { title }\end{array}$} & \multicolumn{9}{|c|}{ Year } & \multirow{2}{*}{$\begin{array}{c}\text { The } \\
\text { rate of } \\
\text { growt } \\
\text { h, in } \\
\text { times }\end{array}$} \\
\hline & 2010 & 2011 & 2012 & 2013 & 2014 & 2015 & 2016 & 2017 & 2018 & \\
\hline $\begin{array}{l}\text { Total } \\
\text { investments } \\
\text { in fixed } \\
\text { assets, } \\
\text { including } \\
\text { by source } \\
\text { of } \\
\text { financing }\end{array}$ & 6625.0 & 8445.2 & 9595.7 & 10065.7 & 10379.6 & 10496.3 & 11282.5 & 12262.2 & 13618.0 & 2.1 \\
\hline $\begin{array}{l}\text { internal } \\
\text { fund }\end{array}$ & 2715.0 & 3539.5 & 4274.6 & 4549.9 & 4742.3 & 5271.1 & 5750.7 & 6290.7 & 7231.1 & 2.7 \\
\hline $\begin{array}{l}\text { borrowed } \\
\text { funds }\end{array}$ & 3910.0 & 4905.7 & 5321.1 & 5515.8 & 5637.3 & 5225.2 & 5531.8 & 5971.5 & 6386.9 & 1.6 \\
\hline bank credit & 595.8 & 725.7 & 806.3 & 1003.6 & 1098.7 & 849.9 & 1174.5 & 1370.1 & 1527.9 & 2.6 \\
\hline $\begin{array}{l}\text { borrowed } \\
\text { funds from } \\
\text { other } \\
\text { organizatio } \\
\text { ns }\end{array}$ & 404.7 & 485.8 & 588.2 & 626.1 & 660.1 & 701.0 & 674.4 & 662.9 & 582.8 & 1.4 \\
\hline $\begin{array}{l}\text { investments } \\
\text { from } \\
\text { abroad }\end{array}$ & - & - & - & 76.4 & 88.8 & 120.4 & 86.7 & 95.8 & 86.6 & 1.1 \\
\hline $\begin{array}{l}\text { budgetary } \\
\text { funds }\end{array}$ & 1294.9 & 1622.0 & 1712.9 & 1916.3 & 1761.3 & 1922.7 & 1856.7 & 2003.4 & 2085.8 & 1.6 \\
\hline $\begin{array}{l}\text { funds from } \\
\text { state extra- }\end{array}$ & 21.0 & 18.2 & 33.3 & 27.9 & 24.0 & 27.3 & 27.8 & 24.5 & 27.5 & 1.3 \\
\hline
\end{tabular}




\begin{tabular}{|l|l|l|l|l|l|l|l|l|l|l|}
\hline $\begin{array}{l}\text { budgetary } \\
\text { funds }\end{array}$ & & & & & & & & & & \\
\hline $\begin{array}{l}\text { funds of } \\
\text { organizatio } \\
\text { ns and } \\
\text { population } \\
\text { on a cost- } \\
\text { sharing } \\
\text { constructio } \\
\text { n }\end{array}$ & 144.2 & 172.7 & 259.5 & 294.9 & 367.6 & 334.3 & 340.7 & 400.0 & 476.6 & 3.3 \\
\hline $\begin{array}{l}\text { including } \\
\text { others }\end{array}$ & 1449.4 & 1881.3 & 1920.9 & 1570.6 & 1636.8 & 1269.6 & 1371.0 & 1414.8 & 1599.7 & 1.1 \\
\hline $\begin{array}{l}\text { funds from } \\
\text { higher- } \\
\text { level } \\
\text { organizatio } \\
\text { ns }\end{array}$ & 1161.8 & 1604.0 & 1615.5 & 1304.1 & 1368.1 & 1412.0 & 1456.1 & 1436.1 & 1513.0 & 1.3 \\
\hline $\begin{array}{l}\text { funds from } \\
\text { corporate } \\
\text { bond issues }\end{array}$ & 0.9 & 0.4 & 4.2 & 1.9 & 5.9 & 6.1 & 7.2 & 6.6 & 7.3 & 8.1 \\
\hline $\begin{array}{l}\text { proceeds } \\
\text { from issue } \\
\text { of shares }\end{array}$ & 72.4 & 82.0 & 95.6 & 100.2 & 116.5 & 122.3 & 126.7 & 132.1 & 138.5 & 1.9 \\
\hline
\end{tabular}

Analysis of investments in fixed assets of economic entities of the Orenburg region for 20102018 shows an annual increase from 103648 million rubles in 2010 to 204238 million rubles in 2018 (Fig.1). Moreover, it should be noted that in 2018, the number of investments in fixed assets increased by 19,361 million rubles, or $110.5 \%$, compared to 2017 . In 2018 , the positive dynamics of investments in fixed assets in this region remained.

million rub.

250000

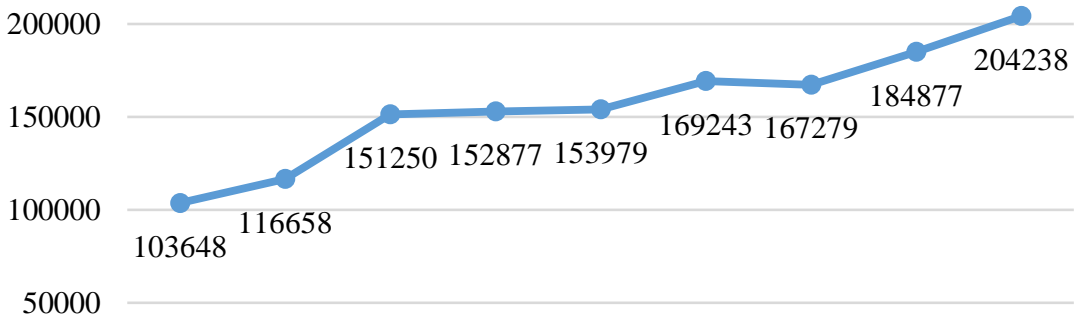

0

2010 y. 2011 y. 2012 у. 2013 у. 2014 y. 2015 y. 2016 y. 2017 y. 2018 y.

- Investments in fixed assets in the Orenburg region

Fig. 1. Investments in fixed assets in the Orenburg region for 2010-2018 [1].

Investments in fixed assets sometimes cover financial fraud, money laundering, largescale bribes, crimes on the securities market, and illegal entrepreneurship. As the result of the world economic crime survey for 2018 show, many Russian economic entities have become victims of economic crimes [21]. One of the reasons for it was a poorly developed system of internal control over securities transactions or its absence. The dynamics of economic crimes in 2010-2018 is presented in table 2 .

Table 2. Dynamics of economic crimes for the years 2010-2018 [15]. 
SHS Web of Conferences 80, 01025 (2020)

https://doi.org/10.1051/shsconf/20208001025

XVII International Conference of Students and Young Scientists "Prospects of Fundamental Sciences Development"

\begin{tabular}{|c|c|c|c|c|c|c|c|c|c|c|}
\hline \multirow{2}{*}{$\begin{array}{c}\text { Economic } \\
\text { crimes }\end{array}$} & \multicolumn{9}{|c|}{ Year } & \multirow{2}{*}{$\begin{array}{l}\text { Growth } \\
\text { rate, \% }\end{array}$} \\
\hline & 2010 & 2011 & 2012 & 2013 & 2014 & 2015 & 2016 & 2017 & 2018 & \\
\hline $\begin{array}{l}\text { Investigations } \\
\text { in criminal } \\
\text { cases }\end{array}$ & 207590 & $\begin{array}{c}17028 \\
8\end{array}$ & $\begin{array}{c}15540 \\
4\end{array}$ & $\begin{array}{c}12644 \\
7\end{array}$ & 97585 & $\begin{array}{c}10244 \\
6\end{array}$ & $\begin{array}{c}9639 \\
5\end{array}$ & 91296 & 97200 & 46.8 \\
\hline $\begin{array}{l}\text { Criminal cases } \\
\text { on the } \\
\text { assignment of } \\
\text { ownership }\end{array}$ & 84759 & 73687 & 72004 & 55783 & 36065 & 35182 & $\begin{array}{c}3467 \\
3\end{array}$ & 33615 & 33873 & 40 \\
\hline $\begin{array}{l}\text { Criminal cases } \\
\text { in the sphere of } \\
\text { economic } \\
\text { activity: }\end{array}$ & 57162 & 40496 & 34405 & 27388 & 26737 & 30028 & $\begin{array}{c}2896 \\
7\end{array}$ & 30042 & 36543 & 63.9 \\
\hline $\begin{array}{l}\text { - illegal } \\
\text { enterprise }\end{array}$ & 791 & 486 & 397 & 401 & 374 & 397 & 342 & 329 & 377 & 47.7 \\
\hline $\begin{array}{l}\text { - manufacture, } \\
\text { storage, } \\
\text { transportation } \\
\text { or sale of } \\
\text { counterfeit } \\
\text { money or } \\
\text { securities }\end{array}$ & 41695 & 29744 & 24073 & 16824 & 20525 & 21136 & $\begin{array}{c}1877 \\
8\end{array}$ & 16290 & 17550 & 42.1 \\
\hline $\begin{array}{l}\text { - production, } \\
\text { acquisition, } \\
\text { storage, } \\
\text { transportation } \\
\text { or sale of goods } \\
\text { and products } \\
\text { without } \\
\text { marking and } \\
\text { (or) applying } \\
\text { information } \\
\text { provided for by } \\
\text { the legislation } \\
\text { of the Russian } \\
\text { Federation }\end{array}$ & 19 & 24 & 28 & 69 & 35 & 40 & 46 & 37 & 56 & $\begin{array}{l}\text { in } 2.9 \\
\text { times }\end{array}$ \\
\hline $\begin{array}{l}\text { - legalization } \\
\text { (laundering) of } \\
\text { money or other } \\
\text { property } \\
\text { acquired by a } \\
\text { person as a } \\
\text { result of } \\
\text { committing a } \\
\text { crime or } \\
\text { acquired by } \\
\text { other persons } \\
\text { through } \\
\text { criminal means }\end{array}$ & 1762 & 704 & 611 & 582 & 774 & 863 & 818 & 711 & 993 & 56.4 \\
\hline $\begin{array}{l}- \text { - illegal } \\
\text { trafficking of } \\
\text { precious metals }\end{array}$ & 985 & 710 & 71 & 81 & 79 & 85 & 102 & 77 & 65 & 6.6 \\
\hline $\begin{array}{l}\text { - illegal actions } \\
\text { in bankruptcy, } \\
\text { deliberate } \\
\text { bankruptcy, } \\
\text { fictitious } \\
\text { bankruptcy }\end{array}$ & 701 & 529 & 474 & 426 & 313 & 279 & 274 & 281 & 271 & 38.7 \\
\hline $\begin{array}{l}\text { Criminal cases } \\
\text { of abuse of } \\
\text { official powers } \\
\text { in commercial } \\
\text { organizations }\end{array}$ & 3185 & 2848 & 2532 & 3663 & 2583 & 3053 & 2100 & 1741 & 1543 & 48.4 \\
\hline $\begin{array}{l}\text { Criminal cases } \\
\text { of abuse of } \\
\text { official powers } \\
\text { in state } \\
\text { authorities }\end{array}$ & 37255 & 34783 & 31010 & 26642 & 19899 & 20571 & 17477 & 12213 & 13262 & 35.6 \\
\hline Others & 94074 & 49640 & 33024 & 27753 & 22513 & 23611 & 25537 & 27476 & 24242 & 25.8 \\
\hline
\end{tabular}


The website of the Ministry of internal Affairs reports that over the period 2010-2018 in the country there was a decrease in the number of economic crimes by $40 \%$. Analysis of table 2 data shows that almost all types of crimes show a decrease in indicators during the study period, except for the production, acquisition, storage, transportation or sale of goods and products without labels (increased by 2.9 times). Crimes for which the investigation is mandatory in 2018 is 97200 , which is almost $48 \%$ less than this figure in 2010 . The largest share of these crimes in 2018 is in the sphere of economic activity-36 543, followed by crimes against property -33873 , and the third place is occupied by other crimes-24 242. As part of crimes in the sphere of economic activity, a significant decrease occurred in such crimes as money laundering or other property by $56 \%$, illegal entrepreneurship by $48 \%$, and the production, storage, transportation or sale of counterfeit money or securities by $42 \%$.

According to the Ministry of internal Affairs of the Russian Federation, economic crimes were registered in 32 regions of our country. According to the Department's calculations, in 2018 the number of crimes in this category increased by $5.9 \%$ compared to 2017 data (Fig.2). According to the number of economic crimes, we can see that the lowest number of detected crimes is in 2017 and is 105.1 thousand cases, and the highest value of this indicator is in $2010-276.4$ thousand cases. In general, the number of detected crimes decreased by $40 \%$ in 2010-2018 the picture is almost the same for crimes that require investigation. The lowest number of crimes is already in 2017 - 91 thousand cases, and the highest value is also observed in 2010 and is 207.5 thousand cases.

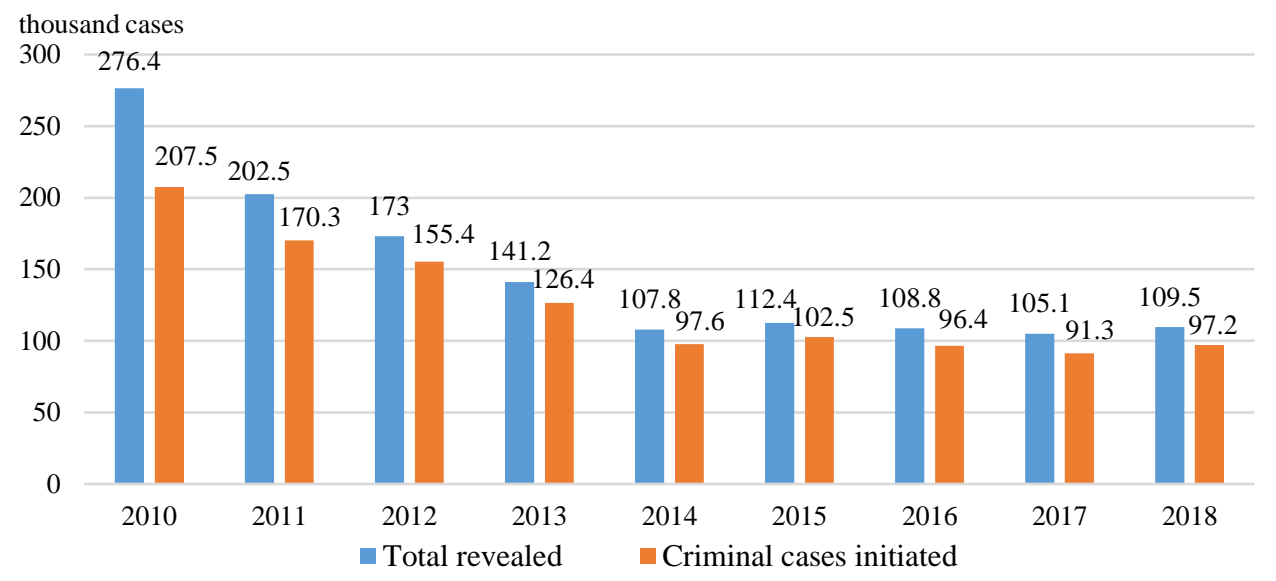

Fig. 2. Identified economic crimes [15].

\section{Discussion}

The growth of economic crimes falls on the economic sphere, which makes it necessary to strengthen control procedures on the part of the owners of the economic entity. For example, some employees of an economic entity may manipulate accounting and reporting data and intentionally mislead users of the reports, due to both fraud and various random factors. The results of the world economic crime survey for 2018, prepared by $\mathrm{PwC}$, show that about half of all fraudsters (48 \%) are employees of an economic entity [21 p. 14]. However, many economic entities in the course of operations on the securities market make a large number of errors in the accounting of securities due to ignorance or incompetence of officials, so they need to apply control procedures in a timely manner to detect and eliminate them. Examples of major errors and violations in the accounting of securities are given in table 3.

Table 3. Typical errors and irregularities in the accounting of securities. 


\begin{tabular}{|c|c|c|c|}
\hline Error content & Error reason & $\begin{array}{c}\text { Possible } \\
\text { consequence }\end{array}$ & $\begin{array}{c}\text { Elimination } \\
\text { recommendations }\end{array}$ \\
\hline $\begin{array}{l}\text { The absence of } \\
\text { title documents } \\
\text { for securities in } \\
\text { the form of } \\
\text { contributions to } \\
\text { the authorized } \\
\text { capital of other } \\
\text { economic entities }\end{array}$ & $\begin{array}{l}\text { Incompetence of } \\
\text { officials of an } \\
\text { economic entity, } \\
\text { fraud }\end{array}$ & $\begin{array}{l}\text { The violation of the } \\
\text { principle of } \\
\text { reliability of } \\
\text { accounting financial } \\
\text { statements }\end{array}$ & $\begin{array}{l}\text { Employees of this economic } \\
\text { entity need to check the } \\
\text { composition and correct } \\
\text { documentation of transactions } \\
\text { with securities in order to } \\
\text { exclude the possibility of the } \\
\text { described error. It is also } \\
\text { necessary to strengthen } \\
\text { control over accounting for } \\
\text { investments in securities }\end{array}$ \\
\hline $\begin{array}{l}\text { Violation of the } \\
\text { established } \\
\text { requirements for } \\
\text { registration of } \\
\text { documents }\end{array}$ & $\begin{array}{c}\text { Incompetence of } \\
\text { officials and low } \\
\text { level of } \\
\text { qualification of } \\
\text { accounting staff, } \\
\text { fraud }\end{array}$ & $\begin{array}{l}\text { Violation of the } \\
\text { principle of } \\
\text { reliability of } \\
\text { accounting financial } \\
\text { statements }\end{array}$ & $\begin{array}{l}\text { Improving the skills of } \\
\text { accounting staff, } \\
\text { strengthening control over } \\
\text { accounting for investments in } \\
\text { securities }\end{array}$ \\
\hline $\begin{array}{l}\text { The lack of } \\
\text { genuine or } \\
\text { authenticated in } \\
\text { accordance with } \\
\text { the legislation of } \\
\text { documents }\end{array}$ & $\begin{array}{c}\text { Incompetence of } \\
\text { officials and low } \\
\text { level of } \\
\text { qualification of } \\
\text { accounting staff }\end{array}$ & $\begin{array}{l}\text { Violation of the } \\
\text { principle of } \\
\text { reliability of } \\
\text { accounting financial } \\
\text { statements }\end{array}$ & $\begin{array}{l}\text { Improving the skills of } \\
\text { accounting staff, } \\
\text { strengthening control over } \\
\text { accounting for investments in } \\
\text { securities }\end{array}$ \\
\hline $\begin{array}{c}\text { Forging } \\
\text { documents or } \\
\text { securities } \\
\text { transactions }\end{array}$ & $\begin{array}{c}\text { Incompetence of } \\
\text { officials and low } \\
\text { level of } \\
\text { qualification of } \\
\text { accounting staff, } \\
\text { fraud }\end{array}$ & $\begin{array}{l}\text { Criminal } \\
\text { prosecution of } \\
\text { officials of an } \\
\text { economic entity, } \\
\text { Accrual of penalties } \\
\text { by a public } \\
\text { authority }\end{array}$ & $\begin{array}{l}\text { Prevention of offenses by } \\
\text { applying a combination of } \\
\text { legal, organizational and } \\
\text { informational measures aimed } \\
\text { at identifying and eliminating } \\
\text { the causes and conditions } \\
\text { conducive to committing } \\
\text { offenses, as well as providing } \\
\text { educational impact on } \\
\text { individuals in order to prevent } \\
\text { the commission of offenses }\end{array}$ \\
\hline $\begin{array}{l}\text { Incorrect } \\
\text { correspondence of } \\
\text { accounts in } \\
\text { accounting when } \\
\text { reflecting } \\
\text { operations with } \\
\text { securities } \\
\end{array}$ & $\begin{array}{c}\text { Incompetence of } \\
\text { officials and low } \\
\text { level of } \\
\text { qualification of } \\
\text { accounting staff }\end{array}$ & $\begin{array}{l}\text { Violation of } \\
\text { securities } \\
\text { accounting } \\
\text { methodology }\end{array}$ & $\begin{array}{l}\text { Making corrections, } \\
\text { Improving the skills of } \\
\text { accounting staff }\end{array}$ \\
\hline $\begin{array}{l}\text { Mismatch of data } \\
\text { on analytical and } \\
\text { synthetic } \\
\text { accounting of } \\
\text { securities } \\
\end{array}$ & $\begin{array}{c}\text { Incompetence of } \\
\text { officials and low } \\
\text { level of } \\
\text { qualification of } \\
\text { accounting staff }\end{array}$ & $\begin{array}{l}\text { Violation of } \\
\text { securities } \\
\text { accounting } \\
\text { methodology }\end{array}$ & $\begin{array}{l}\text { Making corrections, } \\
\text { Improving the skills of } \\
\text { accounting staff }\end{array}$ \\
\hline $\begin{array}{l}\text { Erroneous income } \\
\text { tax }\end{array}$ & $\begin{array}{c}\text { Incompetence of } \\
\text { officials and low } \\
\text { level of } \\
\text { qualification of } \\
\text { accounting staff }\end{array}$ & $\begin{array}{c}\text { Accrual of penalties } \\
\text { by a public } \\
\text { authority }\end{array}$ & $\begin{array}{l}\text { Improving the skills of } \\
\text { accounting staff, } \\
\text { strengthening control over } \\
\text { accounting for investments in } \\
\text { securities, Amendments to the } \\
\text { financial statements of an } \\
\text { economic entity and tax } \\
\text { return }\end{array}$ \\
\hline
\end{tabular}




\begin{tabular}{|c|c|c|c|}
\hline $\begin{array}{l}\text { Inventory of } \\
\text { securities with } \\
\text { violations }\end{array}$ & $\begin{array}{c}\text { Incompetence of } \\
\text { officials and low } \\
\text { level of } \\
\text { qualification of } \\
\text { accounting staff }\end{array}$ & $\begin{array}{c}\text { Violation of } \\
\text { securities } \\
\text { accounting } \\
\text { methodology, } \\
\text { Violation of the } \\
\text { principle of } \\
\text { reliability of } \\
\text { accounting financial } \\
\text { statements }\end{array}$ & $\begin{array}{l}\text { Checking the composition } \\
\text { and types of securities, } \\
\text { Improving the skills of } \\
\text { accounting staff }\end{array}$ \\
\hline $\begin{array}{l}\text { Payment of a } \\
\text { share in the } \\
\text { formed authorized } \\
\text { capital by non- } \\
\text { monetary assets } \\
\text { without an } \\
\text { independent } \\
\text { appraisal }\end{array}$ & $\begin{array}{c}\text { Incompetence of } \\
\text { officials and low } \\
\text { level of } \\
\text { qualification of } \\
\text { accounting staff }\end{array}$ & $\begin{array}{l}\text { Subsidiary liability } \\
\text { of organization } \\
\text { officials }\end{array}$ & $\begin{array}{c}\text { Amendments to the financial } \\
\text { statements of an economic } \\
\text { entity }\end{array}$ \\
\hline $\begin{array}{l}\text { Recognition as a } \\
\text { part of short-term } \\
\text { financial } \\
\text { investments of } \\
\text { own shares } \\
\text { repurchased from } \\
\text { shareholders }\end{array}$ & $\begin{array}{c}\text { Incompetence of } \\
\text { officials and low } \\
\text { level of } \\
\text { qualification of } \\
\text { accounting staff }\end{array}$ & $\begin{array}{c}\text { Violation of } \\
\text { securities } \\
\text { accounting } \\
\text { methodology, } \\
\text { Violation of the } \\
\text { principle of } \\
\text { reliability of } \\
\text { accounting financial } \\
\text { statements }\end{array}$ & $\begin{array}{c}\text { Amendments to the financial } \\
\text { statements of an economic } \\
\text { entity }\end{array}$ \\
\hline
\end{tabular}

Often, the lack of internal control or its improper organization is the reason for refusal to meet the requirements of the business entity. For example, according to the decision of the thirteenth arbitration court in case no. 13AP-20858/2019, a decision was made to refuse to satisfy the appeal because the applicant revealed violations that resulted in failure to ensure the organization and implementation of internal control over operations with securities [20].

The same conclusion was made by the ninth arbitration court of appeal in case no. A40$56109 / 2017$, when the applicant did not show due care and responsibility when recording transactions with securities in accounting, and did not sufficiently exercise internal control over this area of accounting [19].

Errors, omissions, and fraudulent actions cause significant difficulties in the organization of securities accounting. In order to prevent errors and fraud, an economic entity, in our opinion, should regularly carry out control measures for accounting for securities according to a certain method for purchased and available securities (Fig.3). The proposed methodology consists of two sets of tools:

1) determining the effectiveness of purchased and available securities;

2) determining the completeness, reliability and information content of the security. 
The methodology of control procedures for the availability and evaluation of securities of an economic entity

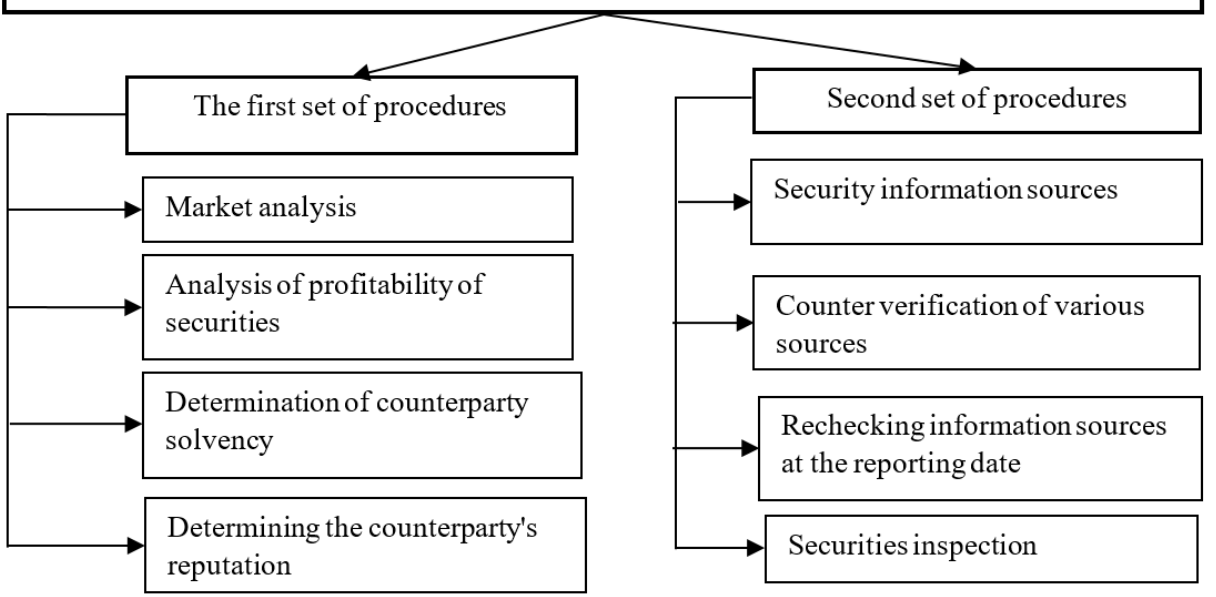

Fig. 3. The methodology of control procedures for checking the availability and evaluation of securities proposed by the authors.

During the implementation of the methodology, the effectiveness of securities is monitored, the possible risks and the amount of expected income from the ownership of this security are studied, the reliability of the counterparty is analyzed and the data obtained is compared with alternative investment options. Analyzing the situation on the securities market it is necessary to study the change in prices for the purchased security in order to predict the further development of its exchange rate. Over the securities yield analysis, the estimated real and nominal income for the security is calculated and compared. When determining the solvency and reputation of counterparties, it should be calculated financial coefficients, as well as analyze previous transactions with securities. In other words, to control the effectiveness of purchased and existing securities, it is necessary to calculate indicators both in quantitative terms (assessment of the received income from investing in these securities) and in qualitative terms (study of the structure of long-term and short-term securities, as well as comparison with previous reporting periods).

When implementing the second set of tools, the methodology of control procedures evaluate the completeness, reliability and information content of a particular security by examining the composition and correctness of the execution of contracts, acts and other documents that are the starting point for generating information in accounting. In addition, we should check publicly available sources of information such as quotes and loan terms. Inspection of securities is carried out by checking the records of deposits to the authorized capital of securities, as well as the reliability of their assessment.

The proposed methodology of control procedures for checking the availability and evaluation of securities serves as a tool for preventing economic crimes. In addition, the use of control procedures allows you to see how effectively decisions are made to conclude transactions with securities; how often management receives analytical information about transactions with securities or information about a significant change in the price of the purchased security. In addition, the use of control procedures allows you to see how effectively decisions are made to conclude transactions with securities; how often management receives analytical information about transactions with securities or information about a significant change in the price of the purchased security. 
Based on the methodology of control procedures for the availability and evaluation of securities, distortions in the financial statements of an economic entity are identified. The analysis of securities yield, sources of information and other elements of the verification methodology allow comparing changes in absolute and relative indicators, studying the reasons for such changes, checking the reliability of calculations of the amounts of income received in the form of interest or dividends, tax calculations, and indicators of accounting financial statements. Crosschecking various sources allows us to determine the actual transfer, receipt of securities, their payment or receipt of income on them.

\section{Conclusion}

In summary, it should be noted, that although the number of investments is increasing every year, the number of crimes is one of the main factors limiting the development of this sphere. There is also a high probability of errors or omissions in accounting when carrying out operations on the securities market due to ignorance or incompetence of officials. Therefore, an economic entity must not only competently and correctly organize internal control, but also conduct audits in order to prevent possible errors and fraudulent actions in the accounting of securities. The proposed methodology of control procedures for checking the availability and evaluation of securities will allow for continuous and comprehensive internal control, as a result of which the number of unintentional errors and fraudulent actions of employees will be minimized, that is, it is one of the main tools for preventing economic crimes.

\section{References}

1. T. Adkins. Financial Statement Manipulation. Laws \& Regulations. Crime \& Fraud https://www.investopedia.com/articles/fundamental-analysis/financial-statementmanipulation.asp (2019)

2. W.S.Mohamed, M.M. Elewa, The Impact of Corporate Governance on Stock Price and Trade Volume, IJAFR, 2(6), 27-44 (2016).

3. V.S. Plotnikov, O.V. Plotnikova, M.V. Bezhan Financial capital accounting procedures and respective comments, Digest Finance, 23(3), 243-253 (2018)

4. I. Qizam, M. Fong Developing financial disclosure quality in sukuk and bond market: Evidence from Indonesia, Malaysia, and Australia, Borsa Istanbul Review, 19(3), 228248 (2019)

5. G.D. Bodner, Financial investments of organizations of the Russian Federation: state and potential growth opportunities, Scientific Herald: finance, banks, investments, 4, 131-141 (2018)

6. V.G. Getman, Improving the accounting of financial investments, International Accounting, 46 (196), 9-13 (2011)

7. T.Yu. Druzhilovskaya, S.M. Romashova, Problems of revenue accounting in systems of Russian and international standards, Accounting in budgetary and non-profit organizations, 2, 2-11 (2016).

8. V.N. Zhukov, Actual issues of internal control of financial investments. Financial analytics: problems and solutions, 3(327), 43-52 (2015)

9. E.A. Kulina, A.A. Kurilova, Accounting and evaluation of financial investments, Bulletin of NIIEI, 9(52), 50-53 (2015) 
10. M.A. Kuts, Typical errors in accounting and financial reporting, identified during the audit, and ways to solve them. Modern research and innovation, 4, http://web.snauka.ru/issues/2017/04/81447 (2017)

11. O.V. Likhtarova, Information support of audit of transactions with financial instruments of the securities market, Azimuth of scientific research: economics and management, 1(14), 5, 27-30 (2016)

12. L.A. Melnikova, Audit of financial investments, Modern accounting, 8 , https://www.lawmix.ru/bux/98902 (2005)

13. N.A. Odegova, Accounting and internal control of the formation and use of debt financial investments: PhD Thesis, 08.00.12. Financial University under the Government of the Russian Federation, Moscow (2014).

14. G.Ya. Ostaev, Organization and implementation of the system of internal audit of financial investments, Accounting in budget and non-profit organizations, 15, 36-47 (2016)

15. The official website of the Ministry of Internal Affairs of the Russian Federation. A brief description of the state of crime in the Russian Federation for the period 20102018. https: //xn--b1aew.xn--p1ai/reports (2020)

16. The official website of the Federal State Statistics Service. http://old.gks.ru/wps/wcm/connect/rosstat_main/rosstat/ru/statistics/enterprise/investm ent/nonfinancial/\# (2020).

17. A.V. Pasechnik, Problems of reflection of financial investments in the financial statements of commercial organizations, Accounting and Statistics, 17, 29-34 (2010)

18. T.V. Pashchenko, K.Yu. Tarasova, Methodological approaches to the assessment of financial investments for the purposes of preparing financial statements and examining the book value of assets, Problems of the Modern Economy, 4(64), 82-86 (2017)

19. Resolution of October 26, 2017 in case № A40-56109/2017. (14 January 2020) Judicial and regulatory acts of the Russian Federation. https://sudact.ru/arbitral/doc/xq3PLF8RvQbt/

20. Decree of October 4, 2019 in case \# A56-54084/2019. (14 January 2020) Thirteenth Arbitration Court of Appeal. http://13aas.arbitr.ru/cases/cdoc?docnd=842184480

21. Russian review of economic crimes for 2018. (14 January 2020). https://www.pwc.ru/ru/publications/recs-2018.html 